\title{
Honey Quality and Safety Control in The Altai Territory
}

\author{
Nadezhda Lunyova*, Valentina Razumovskaya, Olga Kronevald, and Olga Dutova \\ Altai State Agricultural University, Russia
}

\begin{abstract}
Due to a number of factors, "Altai honey" is a branded product. The article describes factors that affect the quality and safety of honey in the Altai Territory. Honey samples taken in different municipal districts of the Altai Territory were tested. It was concluded that organoleptic indicators, quality and safety indicators, the presence of toxic elements, radionuclides and medicines correspond to the regulatory documents. Counterfeit honey is not supplied to the markets and food fairs of the region; however, there were honey samples with poor physical and chemical characteristics, which indicates the early harvest of honey and the untimely use of means for preventing and treating infectious diseases in bee colonies. The well-being of apiaries is registered in veterinary and sanitary passports, which are issued by the state veterinary service in agreement with the owner. The epizootological monitoring revealed that among infectious diseases, nosematosis, aspergillosis and varroatosis are more common.
\end{abstract}

\section{Introduction}

People are increasingly paying attention to their health and aware of the dependence of its quality on the food consumed. Honey is one of the most valuable foods.

In accordance with the rational nutrition recommendations as part of the Technical Regulations of the Customs Union "On food safety", beekeeping products are one of the most important elements of optimization of nutrition and public health, alternative sources of food and biological active substances, which contributes to the expansion of the market beekeeping products [1].

Honey is a natural product with a high content of vitamins, enzymes, macro- and microelements, and other useful substances. Natural honey is an excellent dietary product. But the value of honey is not limited only to its nutritional value, its rich and varied chemical composition, exceptional aroma and taste have made it a folk remedy. Natural honey is a valuable food product which has pronounced therapeutic, dietary and prophylactic properties [2, 3].

Honey can be harmful to health if it is of poor quality or falsified.

Natural honey production is costly. High prices for natural honey make it the subject of widespread falsification.

Compliance with the quality and safety requirements is controlled by modern methods.

Due to the problems of the industry, including cases of falsification, in July 2020, the State Duma of the Russian Federation developed the bill "On beekeeping in the Russian Federation" intended to regulate the legal framework for development and state support of honey production.

A large number of domestic and foreign scientists have been engaged in research on the quality of honey.
This issue is relevant and significant. The problem of providing the population with high-quality and safe beekeeping products is multifaceted and a complex system of measures is required to solve it. To develop effective measures, it is necessary to understand the specifics of the industry and factors that affect it.

The purpose of the research is to study factors that influence the honey quality and safety in the Altai Territory.

\section{Materials and methods}

The object of testing was natural honey produced by beekeepers in the Altai Territory. To determine the quality and safety of honey, tests were conducted, and data of the Altai Regional Veterinary Center for the Prevention and Diagnosis of Animal Diseases in Barnaul were used.

To assess the quality and safety of natural honey, tests were conducted using the methods described in the current scientific and technical documents:

- Organoleptic indicators (GOST 19792-2017 Natural honey. Specifications [2]).

- Quality indicators (GOST 31768-2012. Natural honey. Methods for determination of hydroxymethylfurfural [4], GOST 31770-2012. Method for determination of electrical conductivity [5], GOST 31774-2012. Honey. Refractometric method for determination of water [6], GOST 32167 2013. Method for determination of sugars [7], GOST 32169-2013. Methods for determination of $\mathrm{pH}$ and free acidity [8], GOST 34232-2017. Methods for determination of sucrase activity, diastase number, insoluble substances [9]).

\footnotetext{
Corresponding author: lunyovan@mail.ru
} 
- Toxic elements (GOST 31628-2012. Food products and food raw materials. Stripping voltammetric method for determining the mass concentration of arsenic [10], GOST R 56634-2015. Beekeeping products. Atomic absorption method for the determination of toxic elements [11], MU 2142- 80 Guidelines for the determination of organochlorine pesticides in water, food, feed and tobacco products by thin layer chromatography [12]).

Radionuclides (GOST 32163-2013. Food products. Method for determination of strontium content Sr-90 [13], GOST 32161-2013. Food products. Method for determination of Cs-137 content [14]).

Antibiotics (GOST R 54655-2011. Natural honey. Method for the determination of antibiotics [15]).

The samples were tested on the laboratory equipment for compliance with GOST 19792-2017 - Natural honey. Technical conditions and TR CU 021/2011 Technical regulations of the Customs Union "On food safety" $[1,2]$.

The quality and safety of natural honey is influenced by the veterinary well-being of apiaries. The control over the spread of infectious diseases was exercised by accredited veterinary laboratories; the tests were conducted by the methods approved in the Russian Federation.

The material was taken from the apiaries of the Altai Territory. For quality indicators, 5304 samples were tested; for safety indicators, 317 honey samples were tested. 61807 studies on bee diseases were carried out; tests were conducted for the following infectious diseases: American foulbrood, European foulbrood, parasiticus, achiranidosis, braulosis, varroatosis, nosematosis, amebiasis [16-19].

\section{Results and discussion}

Altai honey is one of the most famous and popular honey in Russia. Its fame is due to high quality indicators, unique taste and aroma. The main reason is a combination of natural and climatic zones in the region and a wide variety of plant species. The ecological purity of the region is achieved due to the low population density, weak urbanization and a small number of industrial enterprises.

Due to the popularity of this product, there is fake Altai honey on the market. There is not much real Altai honey, while Chinese companies buy up a significant part of it.

In the Altai Territory, the law "On beekeeping" approved on December 6, 2010 [20] allows beekeepers to plan the breeding of honey bees, fulfill the requirements for their maintenance, protect from dangerous infectious diseases, and place apiaries in places where honey plants and entomophilous crops grow. The law allows increasing the production of beekeeping products and protecting the rights and interests of beekeeping enterprises.

The quality and safety of honey depends on a number of factors. For example, the composition of minerals in honey depends on their content in the nectar, that is, on the botanical origin of honey. The chemical composition of honey can vary depending on the geographic location and climatic conditions.

The main factors that determine the quality and safety of honey are as follows:

Collection area. This factor depends on the location of an apiary and the environment around this area.

Altai Territory is a unique region in terms of natural and climatic conditions and geographical location. In terms of the landscape, its territory is divided into three parts: plain, foothill and mountain ones. There are many natural and plant contrasts - from semi-deserts and steppes to alpine meadows and highlands, vast deciduous and coniferous massifs in the form of ribbon pine forests, dark taiga and numerous hills.

Sources of pollution are technogenic (industrial emissions, namely heavy metals and toxic metalloids, chemicals, radionuclides, etc.)

Honey contains many essential trace elements that come from raw materials collected by bees. Heavy metals, as an integral part of all industrial emissions, are capable of migrating along power circuits. By the presence of heavy metals in beekeeping products, one can judge about the level of environmental pollution. Therefore, the selection of ecologically clean areas is the key to quality products.

The level of trace elements in both food and beekeeping products depends on the concentration of minerals in the soil, water and air. Despite high concentrations of technogenic elements in the soil, their content in plants decreases. In the secretion of nectar, there is a further decrease in toxic substances. When processing nectar by the bee, some of the chemicals are adsorbed by bee tissues, which decreases the content of heavy metals in honey.

The Altai region lacks this group of pollutants due to the poorly developed chemical and heavy industries.

The second pollutant is pesticides. Farmers and agricultural enterprises cultivate fields during the active summer of bees, without prior informing beekeepers about their activities which causes poisoning and deaths of worker bees. Unfortunately, many beekeepers do not pay attention to this problem. Apiaries are often located in settlements, near agricultural enterprises (farms) and highways. This negatively affects the environmental parameters of beekeeping products.

Deaths of bee colonies and weakening of their strength are observed. Medicines used to combat bee diseases can accumulate in beekeeping products and have a negative effect on humans.

In order to confirm the safety of natural honey for human health, 317 honey samples were tested for the content of toxic elements and compliance with GOST 19792-2017. Natural honey. Technical conditions and TR CU 021/2011 Technical regulations of the Customs Union "On food safety" (Table 1). 
Table 1. Results of testing natural honey from apiaries of the Altai Territory for the content of toxic elements

\begin{tabular}{|c|c|c|c|c|}
\hline $\begin{array}{c}\text { Name } \\
\text { of the } \\
\text { indicator }\end{array}$ & $\begin{array}{c}\text { Number } \\
\text { of } \\
\text { samples }\end{array}$ & $\begin{array}{c}\text { Measurement } \\
\text { units }\end{array}$ & Standard & Results \\
\hline $\mathrm{Cd}$ & 275 & $\mathrm{mg} / \mathrm{kg}$ & $\begin{array}{c}\text { No more } \\
\text { than } 0.05\end{array}$ & Not found \\
\hline $\mathrm{As}$ & 257 & $\mathrm{mg} / \mathrm{kg}$ & $\begin{array}{c}\text { No more } \\
\text { than } 0.5\end{array}$ & Not found \\
\hline $\mathrm{Pb}$ & 275 & $\mathrm{mg} / \mathrm{kg}$ & $\begin{array}{c}\text { No more } \\
\text { than } 1.0\end{array}$ & Not found \\
\hline Pesticides & 317 & $\mathrm{mg} / \mathrm{kg}$ & $\begin{array}{c}\text { No more } \\
\text { than } 0.005\end{array}$ & Not found \\
\hline Sr-90 & 104 & $\mathrm{Bx} / \mathrm{kg}$ & - & Not found \\
\hline $\mathrm{Cs}-137$ & 104 & $\mathrm{Bx} / \mathrm{kg}$ & - & Not found \\
\hline Antibiotics & 984 & $\mathrm{mg} / \mathrm{kg}$ & $\begin{array}{c}\text { not } \\
\text { allowed } \\
\text { (no more } \\
\text { than } 0.01 \text { ) }\end{array}$ & $\begin{array}{c}\text { In } 11 \\
\text { samples the } \\
\text { indicator is } \\
\text { excessive }\end{array}$ \\
\hline
\end{tabular}

According to the test results, it was found that antibiotics were detected in 11 samples. No other toxic elements were found, which confirms the chemical safety of Altai honey.

The botanical composition of plants. The climatic conditions of the Altai Territory make it possible to produce valuable varieties of honey, which have their unique taste and healing qualities. The botanical composition of herbs directly affects the organoleptic qualities of honey.

According to the dominant melliferous plant, Altai honey can be divided into monofloral and polyfloral. Among the monofloral honey, the most common are buckwheat, sainfoin, melilot, sunflower, and rapeseed. More rare types of Altai monofloral honey include acacia, angelica, milkweed, fireweed and others.

Depending on the botanical origin, honey differs in color, taste, aroma and minerals, which affects the taste preferences of consumers. The content of pollen grains of some plants can provoke allergic reactions, but this does not affect the safety of honey.

By its usefulness (biological and physiological value), buckwheat honey ranks first. It contains a large amount of minerals, including iron, valuable proteins and carbohydrates. Buckwheat honey increases the level of hemoglobin, cleanses blood vessels, renews blood, and regenerates damaged tissues.

The second most useful honey is acacia honey. It is absorbed by the body without provoking allergic reactions. Acacia honey has a sedative effect. It is suitable for dietetic nutrition, as it contains enzymes that improve digestion.

Melilot honey is considered no less valuable for the human body. It contains coumarin, which is a blood thinner. Regular consumption helps to prevent heart attacks and strokes.

Along with plants that have a beneficial effect on human health, there are herbs that negatively affect the quality of honey: tall aconite, black henbane, marsh wild rosemary, wolf's bast, Lobel's hellebore, caustic buttercup, raven's eye, golden starlet, poisonous milestone. During the flowering period, these plants can cause deaths of bees. In some cases, beekeepers observe the death of bees when collecting nectar of plants such as high aconite, black henbane, poisonous milestone, raven's eye, Lobel's hellebore. The alkaloids and glycosides in these plants can be converted into nectar. In this case, honey has a dark color (red-brown), thick consistency, bitter taste and turbidity. Honey from such plants is dangerous.

All these plants are ubiquitous in the Altai Territory.

Nectar collected from coniferous trees, cornflower, dandelion, and rape is prone to the formation of bitterness. Coniferous honey of a gray-green color, has a spicy smell, and a bitter taste. The bitterness is usually not harmful. The reasons for bitterness can be a violation of the rules of collection and storage of finished products, non-observance of the temperature regime, as well as collection of nectar from plants with a bitter taste (wormwood, yarrow, etc.).

Bee diseases and drugs. The monitoring of infectious bee diseases made it possible to determine that nosematosis, aspergillosis and varroatosis are more common than other diseases in the Altai Territory.

Medicines were not found in honey, since most beekeepers use them correctly. Preventive and therapeutic measures are taken in early spring and late autumn, which contributes to the timely release of drug residues from the body of bees.

Veterinary drugs belong to the third group of pollutants in beekeeping products. The medicines affect the bee colonies directly in the hives, since this method is most effective in the treatment and prevention of bee diseases. Problems arise when beekeepers neglect recommendations of veterinarians or violate instructions for the use of drugs.

Changes in the composition or properties of honey. This aspect is determined by human activities (manufacturer, distributor, seller). The consequences are identified and monitored with the help of veterinary and sanitary examination of beekeeping products.

Veterinary and sanitary examination of honey is of great importance in ensuring its quality and safety.

High-grade honey is a product that meets GOST 19792-2017.

Defective honey is a product with naturally or artificially altered properties. It can be falsified, toxic, or tainted.

To assess the usefulness and compliance with the quality indicators, 5304 samples were tested. Table 2 shows the results of the veterinary and sanitary examination of honey.

The veterinary and sanitary examination identified that among the samples a deviation from the standards was observed in one sample (it had an excess content of free acidity); in eight samples, an increase in the moisture content was observed. Other indicators allow us to conclude that the honey samples met the established requirements. 
Table 2. Results of the veterinary and sanitary examination of Altai honey

\begin{tabular}{|c|c|c|c|c|}
\hline Name of anindicator & $\begin{array}{c}\text { Number of } \\
\text { samples }\end{array}$ & Measurement unit & Standard & Results \\
\hline Organoleptic indicators & 5304 & - & According to GOST * & corresponds \\
\hline Diastasis number & 5304 & Gothe unit & No less than 8.0 & Within acceptable limits \\
\hline Mass fraction of HMF & 5304 & - & negative & Within acceptable limits \\
\hline $\begin{array}{c}\text { Mass fraction of insoluble } \\
\text { impurities }\end{array}$ & 1672 & $\%$ & No less than 65.0 & Within acceptable limits \\
\hline $\begin{array}{c}\text { Mass fraction of reducing } \\
\text { sugars }\end{array}$ & 5304 & meq/kg & No more than 40.0 & $\begin{array}{c}\text { In the } 1 \text { st sample the } \\
\text { indicator is exceeded }\end{array}$ \\
\hline $\begin{array}{c}\text { Free acidity } \\
\text { Electrical conductivity }\end{array}$ & 5304 & $\mathrm{mS} / \mathrm{cm}$ & No more than 0.8 & Within acceptable limits \\
\hline Moisture & 5304 & $\%$ & No more than 20.0 & $\begin{array}{c}\text { In the eigth sample the } \\
\text { indicator is exceeded }\end{array}$ \\
\hline
\end{tabular}

*Liquid, fully or partially crystallized. The aroma is pleasant, varying from weak to strong, without foreign smell. The taste is sweet, pleasant, without any foreign aftertaste. Signs of fermentation and mechanical impurities are not allowed.

\section{Conclusion}

An analysis of literature data showed that the veterinary and sanitary control of honey is regulated by a large number of documents, but some aspects require amendments to the existing scientific and technical documents (e.g., the botanical origin of honey).

A large assortment, geographical diversity, ecological well-being gives the Altai natural honey uniqueness, nutritional value and trademark status.

The studies made it possible to establish that the samples of natural honey produced in different regions of the Altai Territory, in terms of organoleptic and safety indicators, fully comply with the NTD requirements. However, some physicochemical indicators did not correspond to the regulatory documents.

The measures implemented to ensure the quality and safety of natural honey allowed the region to exclude the supply of unsafe and falsified honey to the market.

Recommendations:

- Consumers should purchase honey which has quality and safety certificates.

- It is necessary to tell people about types of honey falsification and importance of honey quality and safety.

\section{References}

1. TR CU 021/2011, Technical Regulations of the Customs Union "On food safety"

2. GOST 19792-2017, Natural honey. Technical conditions

3. V.I. Lebedev, E.A. Murashova, Beekeeping, 42, 4 (2003)

4. GOST 31768-2012, Natural honey. Methods for the determination of hydroksimetilfurfurat

5. GOST 31770-2012, Honey. Method for determining electrical conductivity
6. GOST

31774-2012,

Honey. Refractometric method for determining water

7. GOST 32167-2013, Honey. Method for the determination of sugars

8. GOST 32169-2013, Honey. Methods for determining $\mathrm{pH}$ and free acidity

9. GOST 34232-2017, Honey. Methods for determining the activity of sucrase, diastase number, insoluble substances

10. GOST 31628-2012, Food products and food raw materials. Stripping voltammetric method for determining the mass concentration of arsenic

11.GOST R 56634-2015, Beekeeping products. Atomic absorption method for the determination of toxic elements

12. MU 2142-80, Guidelines for the determination of organochlorine pesticides in water, food, feed and tobacco products by thin layer chromatography

13.GOST32163-2013, Food products. Method for determination of strontium content Sr-90

14.GOST 32161-2013, Food products. Method for determination of Cs-137 content

15.GOST R 54655-2011, Natural honey. Method for the determination of antibiotics

16. A.V. Aganin, Veter. Med., 60 (2011) 
17. A.P. Belonogov, A.A. Albrecht, N.K. Novichikhina, Diseases of bees in Siberia (Polinkom LLC, Barnaul, 2007)

18. M.I. Gulyukin, O.F. Grobov, How to identify diseases of bees in an apiary? (RAAS, GNU VIEV, Moscow, 2004)
19. A.V. Suvorin, Bees and an apiary. Experience, advice, recommendations (Phoenix, Rostov on Don, 2003)

20. On beekeeping, Law of the Altai Territory of 06.12.2010, no. 110-a 